\title{
Slik er sykepleie i \\ verdens største \\ flyktningleir
}

Det nytter å hjelpe. I denne flyktningleiren i Bangladesh har blant annet antallet dødfødsler gått ned, som følge av innsatsen ved et norsk feltsykehus.

\section{Forfattere}

Åge Bøyum

Intensivsykepleier

Intensivavdelingen, St. Olavs hospital

Anne Kristine Jensen

Intensivsykepleier

Intensivavdelingen, Sykehuset Innlandet

\begin{tabular}{l|l|l|l|l} 
Flyktning Internasjonal helse Internasjonalt samarbeid & Akuttsykepleie
\end{tabular}

Sykepleien 2019 107(76979)(e-76979)

DOI: https://doi.org/10.4220/Sykepleiens.2019.76979

\section{Hovedbudskap}

Flyktningene fra Myanmar har vært i Bangladesh lenge, men siden sommeren 2017 har det kommet mange hundre tusen flere på grunn av den pågående konflikten. Artikkelen skildrer oppretting og drift av feltsykehus og noen store sykepleiefaglige utfordringer. Oppmerksomheten rettes mot noe av det kunnskapsgrunnlaget som ligger til grunn for sykepleie og helsehjelp i internasjonale katastrofesituasjoner. Intensjonen med artikkelen er også å vise hvordan samarbeid og koordinering foregår. 
Siden slutten av august 2017 har flere hundre tusener rohingyaer flyktet fra Myanmar, etter at de ble drevet på flukt av militær makt. De flyktet til nabolandet Bangladesh, som allerede i årtier har huset et par hundre tusen rohingyaer (1). Bangladesh Red Crescent Society (BDRCS) har assistert mennesker som har flyktet fra Myanmar siden 1990-tallet.

Som følge av den massive tilstrømmingen av mennesker fra Myanmar til Bangladesh karakteriserte IFRC (Den internasjonale Røde Kors-føderasjonen) dette som en stor «Kategori rød» nødhjelpsoperasjon. 1,2 millioner mennesker ble vurdert til å være i nød i den sørøstre delen av Bangladesh, distrikt Cox’s Bazar (1). Røde Kors' feltsykehus, Rubber Garden, ble også etablert der i en gummiplantasje.

\section{Avhengig av bistand}

Flyktningene, av dem mange kvinner og barn, var avhengig av humanitær bistand for å overleve. De aller fleste ble boende og bor i provisoriske store leire, under særdeles vanskelige forhold. De flyktet ofte bare med det de sto og gikk i, og mange familier hadde bare presenning å bo under og litt nødhjelpsforsyninger fra forskjellige nødhjelpsorganisasjoner å klare seg med.

Det offentlige helsesystemet i Cox's Bazar var fullstendig overbelastet og klarte ikke å håndtere situasjonen med den ekstreme tilstrømmingen av trengende mennesker. Mange var syke, difteri spedde seg i de provisoriske leirene, og det var mange med gamle skader og med psykiske traumer. Det var stor mangel på profesjonell fødselshjelp.

\section{Ba om hjelp}


Bangladesh gikk ut med en appell om internasjonal nødhjelp. FN og statlige og ikke-statlige organisasjoner (NGO) svarte raskt på appellen. The International Federation of Red Cross (IFRC) responderte med å forespørre Norges Røde Kors, som har sammen med flere nasjonalforeninger spesialisert seg på feltsykehus og på tidlig utsending av slike feltsykehus. Fra alarmen blir sendt ut fra Norges Røde Kors til de cirka 250 fagfolkene på beredskapslisten, går det fra 48 til 72 timer til avreise for feltsykehuset med aktuelt personell. Alt må skje raskt hos Røde Kors, med klargjøring, visumsøknad, pakking, permisjon og brifing.

\section{Forklaringer på forkortelser}

BDRCS - Bangladesh Red Crescent Society (Bangladesh Røde Halvmåne)

EMT 2 - Emergency Medical Team WHO type 2 (grupper med helsepersonell som hjelper ved nødssituasjoner)

ERU - Emergency Response Unit (nødhjelpsenhet)

ICRC - The International Committee of Red Cross (Den Internasjonale Røde Kors Komite)

IFRC - The International Federation of Red Cross and Red Crescent Society (Det internasjonal forbundet av Røde Kors- og Røde Halvmåne-foreninger)

MSF - Médecins Sans Frontières (Leger Uten Grenser)

NGO - Non-Governmental Organization (ikke-statlig organisasjon, er en samlebetegnelse på frivillige, ikke-statlige organisasjoner) 


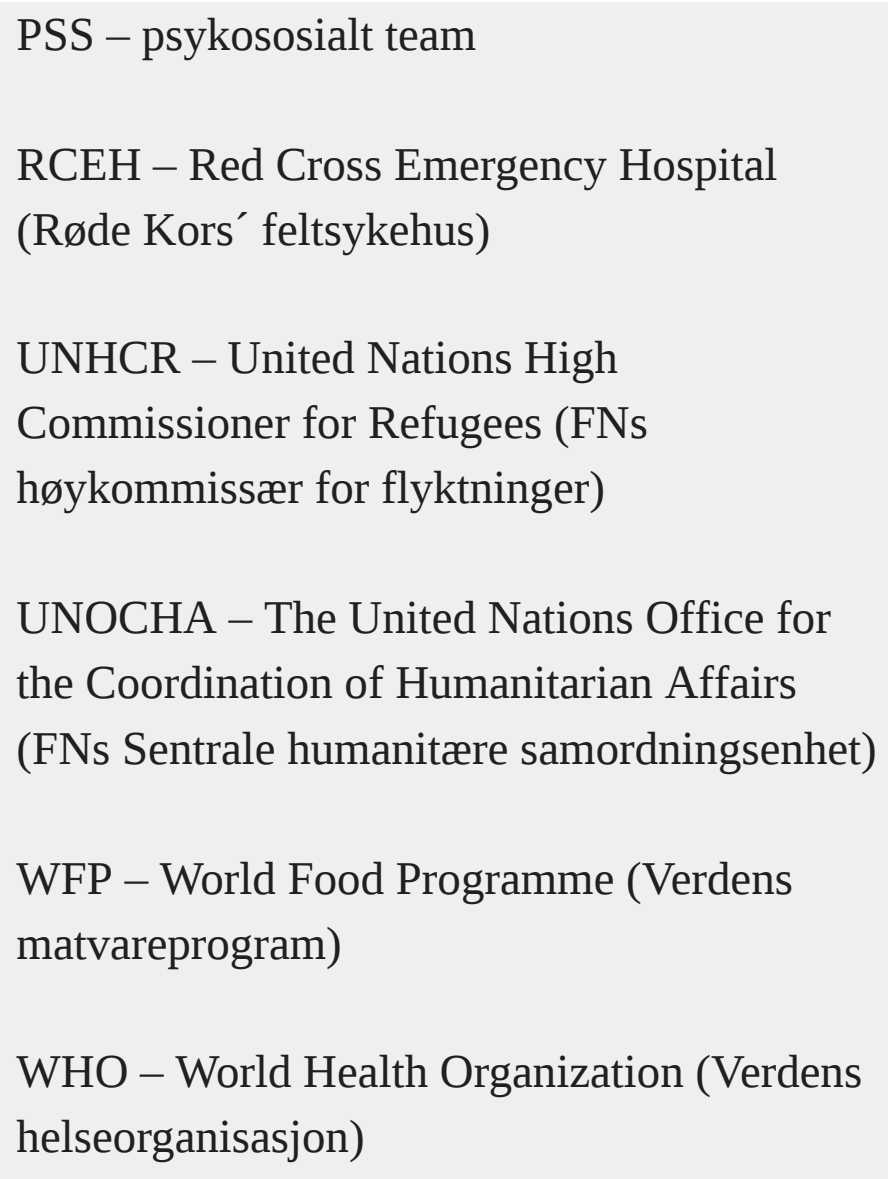

\section{Selvforsynt team}

I enhver slik ERU-utsending er det til stede en blanding av fagpersonell med mer eller mindre erfaring fra internasjonale oppdrag for å sikre kontinuitet. I begynnelsen av en katastrofe er det ofte svært kaotisk, og det er store logistiske utfordringer. Enheten som ble sendt ut til Bangladesh i oktober 2017, var et Red Cross Emergency Hospital (RCEH). Seksti senger med generell kirurgi og obstetrikk, fødeavdeling, barn- og voksenavdeling og poliklinikk ble sendt.

\section{三 «I begynnelsen av en katastrofe er det ofte svært kaotisk.»}


Vekten på ett slikt sykehus er over 60 tonn. Dette innebærer at sykehuset er selvforsynt med alt de første fire til seks ukene, inklusiv medikamenter, mat, vannrensingsutstyr og generatorer med noe drivstoff (4).

Sykehuset er i tråd med det Verdens helseorganisasjon (WHO) benevner som et Emergency Medical Team type 2 (EMT 2), som Helsedirektoratet også har initiert at flere av regionsykehusene i Norge allerede har eller skal opprette $(5,6)$.

\author{
Hva er EMT? \\ EMT er grupper av helsepersonell, leger, \\ sykepleiere, paramedikere osv. som \\ behandler pasienter som er berørt av en \\ nødsituasjon eller katastrofe. De kommer fra \\ regjeringer, veldedige organisasjoner, \\ militære og internasjonale organisasjoner \\ som den internasjonale røde kors / røde \\ halvmånebevegelsen. De jobber for å \\ overholde klassifikasjon og \\ minimumsstandarder fastsatt av WHO og \\ dets partnere. De er selvforsynte for ikke å \\ belaste det nasjonale systemet.
}

Kilde: WHO

Militære feltsykehus har ofte en annen agenda enn et sivilt sykehus, fordi et militært sykehus gjerne er en del av et større militært engasjement. Flere av de vestlige militære utsendingene har vært av det som kalles EMT 3. De militære feltsykehusene har gjerne muligheten til å ha en høyere standard og flere kirurgiske spesialisttjenester, inklusive intensivbehandling. I tillegg har de mulighet til å overføre pasienter til mer avanserte behandlinger og rehabilitering. 
Norges Røde Kors har lang erfaring med rask utsendelse av feltsykehus. Personellet som normalt er i beredskap, arbeider intenst i fire til seks uker når de sendes ut med sykehuset. Deretter erstattes de av en ny gruppe delegater. RCEH, lett feltsykehus, er en del av Norges Røde Kors' bidrag til IFRCs nødhjelpsrespons, Emergency Response Unit (ERU) (7).

Den første tiden av en deployering (utstasjonering) i et nødhjelpsområde er alltid preget av mye kaos, det er ofte knapphet på transportkapasitet og logistikk. Alle store nødhjelpsorganisasjoner er da til stede eller på vei inn. Media pleier å rapportere om økende humanitært behov blant flyktningene, og alt skulle vært fremme på plass og satt opp, helst i går.

\section{Sykehus i regn og søle}

Den som vet hvorfor han lever, kan holde ut et nesten hvilket som helst hvordan (3).

RCEH-enheten fra Norge ble deployert i oktober 2017. Enheten besto i all hovedsak av helsepersonell og teknisk personell. Vel fremme i Bandraban-regionen i Bangladesh var den første utfordringen å finne en egnet tomt å sette opp et stort feltsykehus på. Med personaltelt og alle sykehusteltene, teknisk avdeling og lager krever oppsettet omtrent størrelsen av en fotballbane. Valget falt på en gummiplantasje. Avtale med forpakteren av plantasjen gikk etter hvert i orden, og ved første øyekast var dette et velegnet sted. Etter kort tid satte et kraftig monsunregn en effektiv stopper for en rask oppføring av sykehuset.

Grunnen forvandlet seg til et enormt område med dyp søle og vann, noe som gjorde arbeidsforholdene svært vanskelige. Å sette opp teltene og manuelt håndtere flere tonn med utstyr på ekstremt underlag ble svært krevende. Å følge den opprinnelige fremdriftsplanen ble umulig. Hele området ble grøftet for hånd, og det ble bestilt store mengder grus som i stor grad ble fordelt utover manuelt. 


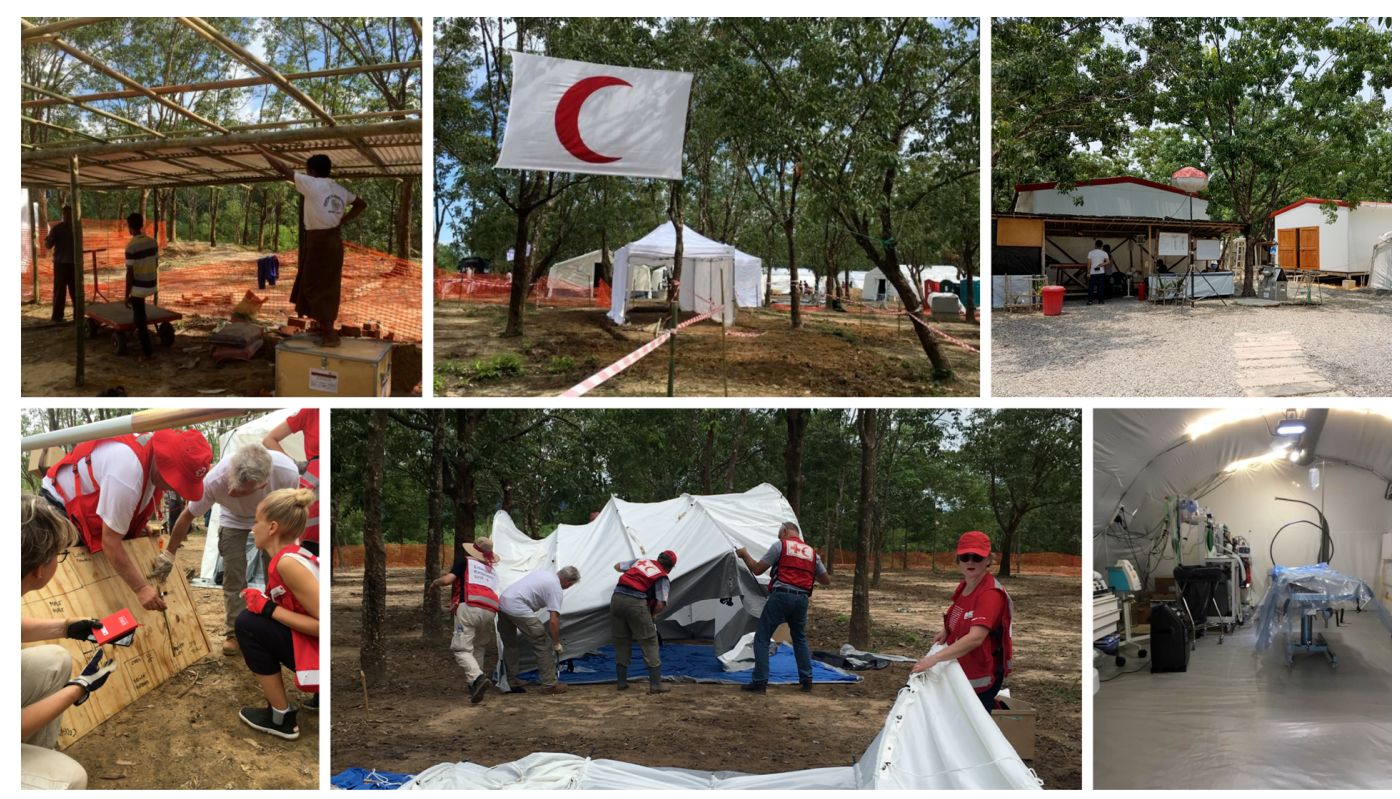

SYKEHUSET TAR FORM: Lokal arbeidskraft ble innleid, og feltsykehuset sto endelig ferdig etter mange arbeidstimer. Foto: Anne Kristine Jensen

Det var problematisk å innta nok mat og drikke for personer fra RCEH-enheten i disse omgivelsene. Den høye luftfuktigheten i kombinasjon med sterk varme gjorde det hele enda mer utfordrende. Det regnet kraftig og kontinuerlig i lange perioder. Å tørke klær var helt umulig. Vi satte opp telt for å bo i dem, men det var lekkasje i dem, og all gjørmen gjorde situasjonen vanskelig generelt, og umulig for klestørk. Flere delegater ble syke.

I samarbeid med BDRCS rekrutterte vi lokalt personale. På den medisinske siden gjaldt dette en kirurg, leger og sykepleiere. Det ble vanskelig å rekruttere godt kvalifisert personale. Det viste seg at legene var svært unge og ennå ikke ferdig uteksaminerte. De var blitt forespeilet å «hjelpe oss» i et par uker, mens vi ønsket å ansette dem for en periode på fire måneder. Dette var de helt uforberedt på.

\section{三 «Det viste seg at legene var svært unge og ennå ikke ferdig uteksaminerte.»}


I Bangladesh, som er et svært klassedelt samfunn, rekrutteres gjerne leger fra overklassen, slik som disse legestudentene. De var selvfølgelig ikke forberedt på å jobbe i en slik ekstremt krevende situasjon under forhold som de aldri hadde sett for seg.

Det ble inngått et kompromiss der legene gikk med på å være i en måned, og etter det skulle de erstattes av en helt ny gruppe like uerfarne legestudenter. For oss ble det problematisk å opprettholde kontinuitet og kvalitet, i og med at vi igjen måtte i gang med opplæring og tilvenning.

For sykepleierne var det også utfordringer. Det viste seg at de ikke var utdannet sykepleiere, men at de var medhjelpere på ulike helseklinikker/sykehus i landet. De kunne ikke engelsk, og kommunikasjonen var et problem i og med at vi ennå ikke hadde ansatt et tilstrekkelig antall tolker. Likevel gjorde alle sitt aller beste, og alle bidro på sitt vis.

\section{Flere trengte hjelp}

Som nevnt er det alltid svært store utfordringer med en utsending. I forhold til i et katastrofeområde etter jordskjelv, der hele infrastrukturen kan være borte, som for eksempel i Nepal i 2015, hadde Bangladesh på tross av monsunen infrastrukturen i behold.

Vanlig utsendingstid (tiden sykehuset er i drift) på et RCEH er fra tre til fem måneder. Arbeidsmengden på sykehusene blir ofte mindre etter andre eller tredje rotasjon. Slik var ikke tilfellet her i Bangladesh. I løpet av de første månedene kom det fortsatt mange flyktninger, og behovet for hjelp avtok ikke, noe som skapte utfordringer med etterfylling av medikamenter og annet utstyr etter de første seks ukene. 
Et annet viktig moment er at når det sendes ut en ERUenhet fra Røde Kors, opererer den aldri i et vakuum.

Det er alltid en Røde Kors-forening eller en Røde Halvmåne-forening der fra før. Slik også i Bangladesh, og samarbeidet med BDRCS har vært helt sentralt for feltsykehusets funksjon. Selv om rekrutteringen av lokalt helsepersonell var en stor utfordring i starten, bedret det seg etter en tid, og BDRCS skaffet oss sjåfører, tolker, portører, renholdspersonell og vakter.

\section{By uten navn}

Flyktningkrisen i Bangladesh eskalerte utover høsten 2017 og det var ingen utsikt til at flyktningene kunne vende tilbake til Myanmar. Flyktningleirene har blitt en by uten navn på mer enn 700000 innbyggere i grenseområdet til Myanmar.
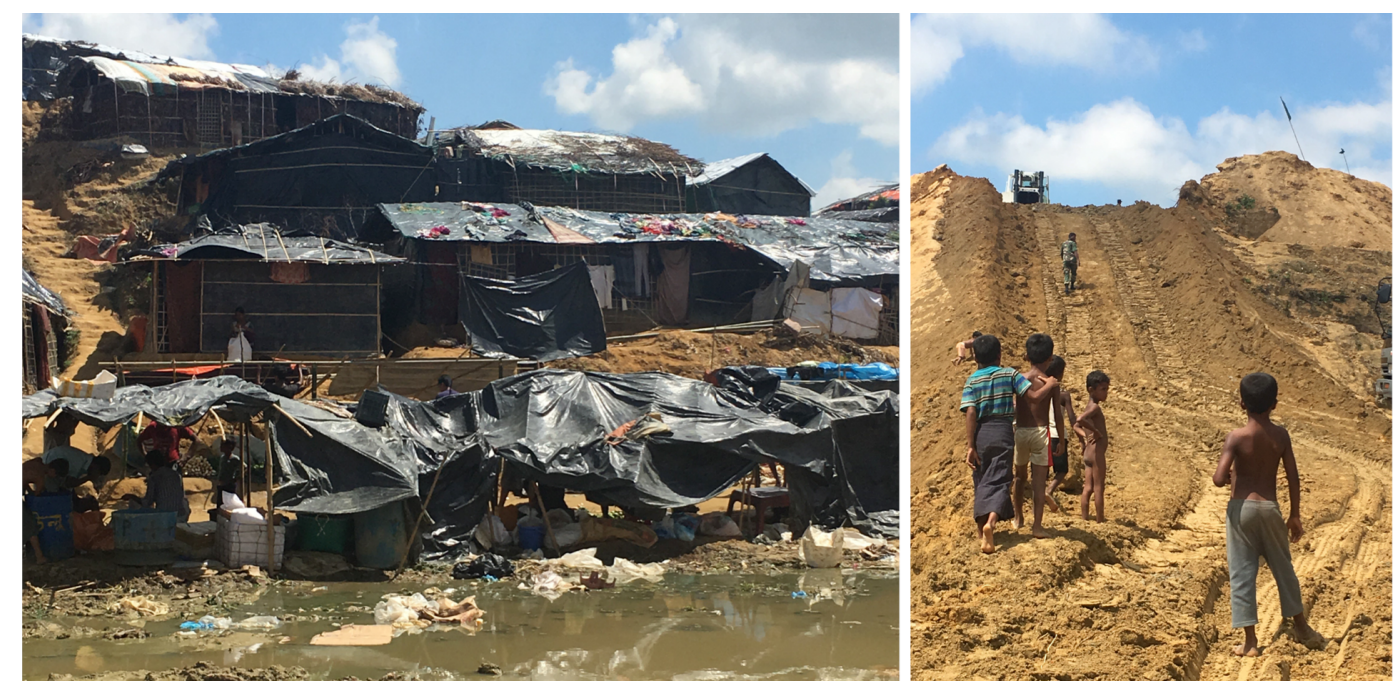

ENKLE FORHOLD: Boforholdene i leiren er krevende. Det ble bygget provisoriske veier over store områder for å utvide flyktningleiren slik at alle flyktningene som kom, fikk plass. (Foto: Anne Kristine Jensen)

I mars 2019 var det fortsatt over 140 forskjellige organisasjoner involvert, både fra forskjellige FNorganisasjoner som WFP (Verdens matvareprogram), UNOCHA (FNs Sentrale humanitære samordningsenhet), WHO og UNHCR, fra andre land (bilaterale avtaler) og ikke minst fra NGO-er. 
Det var mange helseklinikker og feltklinikker til stede i distriktet, men feltsykehus fra Norge var i lang tid det eneste i området som hadde 24/7 kirurgisk/obstetrisk beredskap. Dette gjorde sykehuset svært verdsatt og pasientantallet var høyt.

Figur 1. Pasientdata ved feltsykehuset fra oktober 2017 til oktober 2018

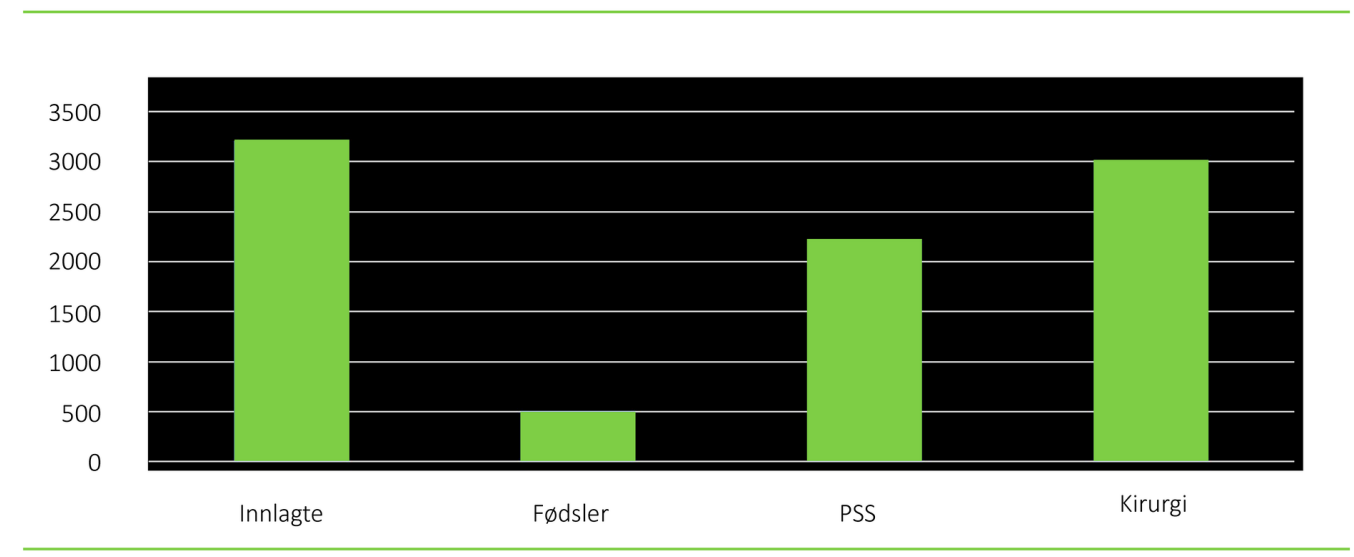

Diagrammet viser ett års aktivitetsnivå angående pasientbehandling på feltsykehuset fra Norge, oktober 2017 til oktober 2018. (Åge Wiberg Bøyum)

På poliklinikken (OPD) ble det på ett år behandlet 45256 pasienter. Til forskjell fra naturkatastrofer som flom, jordskjelv eller sykloner virker flyktningenes situasjon her i Bangladesh mer fastlåst. Selv om det foreligger en avtale om retur av flyktningene, er det til nå svært få som har returnert til Myanmar. Situasjonen slik den var for mer enn ett år siden, er den samme fortsatt, i april 2019. Det er ikke trygt for flyktningene å returnere på grunn av forholdene i Myanmar (8).

\section{Felles forståelse}

Oh, East is East, and West is West, and never the twain shall meet (9).

Alle som er med på en slik utsending, vil alltid måtte arbeide med personell som man ikke har arbeidet med tidligere. Noen er uerfarne og i tillegg vant til andre standarder, protokoller og rutiner. Hvordan opprettholdes en felles god standard? Spesielt under forhold som kan være svært krevende og uvant for de fleste. Hvilket faglig grunnlag arbeides det etter? 
Selv om en nødvendigvis må basere seg på en høy grad av innovasjon og løsningsorientering, er det ikke bare opp til hvert enkelt helsepersonell sine standarder å finne ad-hoc-løsninger og improvisasjoner.

Feltsykehuset sendes ut med en forhåndslagret standardpakke med medikamenter og utstyr, beregnet på skadebehandling, fødsler og infeksjoner. I tillegg benyttes behandlingsprotokoller utgitt av ICRC (Den internasjonale Røde Kors-komiteen), WHO og andre institusjoner. Alltid mangler noe utstyr en gjerne skulle ha hatt, men dette blir et evig kompromiss i forhold til logistikk, behandlingsbehov og muligheter.

Det er skrevet noen fagartikler fra militære feltsykehus, men det er vanskeligere å finne artikler som spesifikt beskriver sykepleiestandarder og prosedyrer på humanitære feltsykehus i katastrofeområder. WHO i samarbeid med andre hjelpeorganisasjoner har imidlertid spesielt etter jordskjelvet i 2010 på Haiti gjort et stort arbeid med å utvikle standarder og prosedyrer til bruk i katastrofesammenheng.

Flere feltguider, prosedyrer, anbefalinger og protokoller har blitt utgitt for eksempel om kolera, injeksjonsbehandling av sår, ebola, begravelse av døde og rehabilitering i katastrofesammenheng. Imidlertid er det alltid kaotisk i en katastrofe under en utsending, og man må prioritere det basale. Derfor er det viktig at personalet er forberedt og kurset på forhånd og kjent med det utstyret og de prosedyrer som er tilgjengelig.

\section{三 «En flyktningkrise, flom, syklon eller et jordskjelv setter ofte hjelpemannskapets innovasjon og fleksibilitet på prøve.»}


En flyktningkrise, flom, syklon eller et jordskjelv setter ofte hjelpemannskapets innovasjon og fleksibilitet på prøve, og en kan ikke overføre de samme standarder og prinsipper på sykehus hjemme til en situasjon med ofte uoversiktlige og svært omfattende helse- og nødhjelpsbehov.

Likevel må ikke prioriteringene gå på tvers av grunnleggende hygieniske, omsorgsmessige, etiske eller behandlingsmessige standarder. I denne sammenheng kan det være på sin plass å peke på at Florence Nightingale delvis utviklet den moderne sykepleien under primitive feltforhold i Krim-krigen (1853-56). Florence Nightingale fikk ned dødeligheten med om lag 40 prosent på feltsykehuset hun arbeidet på, ved å bedre generell hygiene, ernæring og generelt organisatoriske forhold, og i tillegg dokumenterte hun forbedringene statistisk (10).

WHO har også satt noen standarder i sine klassifikasjoner av EMT 1, 2 og 3. Det er for eksempel satt en standard på at det skal være en sykepleier per åtte pasienter ved en EMT 2.

Ut over dette er standarden mer fokusert på organisering og struktur og ikke så mye på spesifikke prosedyrer. Standardene er utarbeidet av internasjonale eksperter innen fagfeltet og med stadige revisjoner (5).

\section{Standardiserte prosedyrer}

ICRC har gjort et stort og viktig arbeid for å standardisere prosedyrer i forhold til krigsskadde ved kurs, bøker og prosedyrer, blant andre en bok om sykehusdrift for krigsofre: Hospitals for War-wounded (11).

Her blir en god del sykepleieprosedyrer beskrevet, hovedsakelig med et klinisk instrumentelt fokus, for eksempel til pasienter med sårskader forårsaket av våpen (11). Noe av det som er beskrevet, kan også brukes i sammenheng med katastrofer. 
Det er utgitt flere bøker og artikler med fokus på behandling. Eksempler på dette er bøkene War surgery Volume 1 og 2. De inneholder riktignok prosedyrer som gjelder for behandling av krigsskader, men flere prosedyrer kan overføres til sårskader generelt, for eksempel «secondary wound closure» av infiserte sår $(12,13)$. Noen sykepleieprosedyrer er inkorporert i bøkene. For eksempel er prosedyrer om postoperativ overvåkning beskrevet både i Nursing Guidelines og i War surgery $(13,14)$. Det som gjør Nursing Guidelines spesielt anvendbar, er at retningslinjene også omhandler pediatri og fødselsomsorg (14).

IFRC er også i gang med å videreutvikle standarder for helsehjelp i katastrofesammenheng. ICRC har utgitt protokoller for sykepleie i Nursing Guidelines vol. 2, sist revidert i 2009 (14). Imidlertid er disse prosedyrene uten henvisninger og dokumentasjon (14).

\section{三 «Noe av intensjonen med en nødhjelpsutsending er at en ikke skal etablere et høyere eller mer avansert behandlingsnivå enn det som befinner seg i landet fra før.»}

Prosedyrene er ikke ment som en fasit, men mer rettet mot en erfaringsbasert faglig støtte til lokalt utarbeidede prosedyrer. ICRC har i tillegg undervisningssykepleiere med på mange av sine prosjekter. Lokalt eierskap er helt sentralt, da prosjektene som regel overlates til lokale myndigheter etter en tid (14). Noe av intensjonen med en nødhjelpsutsending er at en ikke skal etablere et høyere eller mer avansert behandlingsnivå enn det som befinner seg i landet fra før av (14). 
Mange av ICRCs prosjekter går imidlertid over flere tiår, for eksempel i Afghanistan og Sør-Sudan. Der kan en planlegge mer for langvarig kompetanseutvikling, selv om flere av disse prosjektene har blitt lagt ned eller ødelagt som følge av krigshandlinger, for så å begynne på nytt et annet sted. Slik kan det nesten fremstå som et sisyfosarbeid, altså et endeløst og forgjeves arbeid.

Ved feltsykehuset i Rubber Garden ble ICRCs Nursing Guidelines brukt, og det har også vært benyttet ved Røde Kors' feltsykehus tidligere i katastrofeområder. Disse prosedyrene ble også brukt og blir brukt av RCEH-feltsykehuset i Bangladesh.

Protokollene og standardene er strengt klinisk medisinske, men kulturforståelse, omsorg, informasjon og kommunikasjon er helt sentralt og en viktig generell del av Røde Kors-bevegelsens ideologi.

Flere av behandlingsprotokollene er utviklet $\mathrm{i}$ samarbeid mellom organisasjonene (15). Bidragsyterne er internasjonalt anerkjente eksperter. Med behandlingsprotokollen følger også en opplæringsmodul der prosedyrene er rettet mot både sykepleiere og leger (15). I forhold til helsehjelp i katastrofeområder er slike opplæringsverk ikke uvanlige.

\section{Samarbeid mot felles mål}

Det foreligger et utstrakt samarbeid mellom organisasjonene i felt. Leger Uten Grenser (MSF) sine Clinical Guidelines blir brukt ved Røde Kors' feltsykehus, også i Bangladesh, slik som under andre oppdrag. 
MSF og RCEH samarbeidet om overflytting av

pasienter mellom våre klinikker. Spesielt der en på

MSFs klinikker forventer kompliserte fødsler, ble

pasientene overført til vårt feltsykehus på grunn av at vi hadde sectio-beredskap. Fra første januar 2019 har pasienter blitt henvist fra feltsykehuset til en av MSFs klinikker, spesielt når det gjelder syke barn, på grunn av at MSF har en barneavdeling.

På vårt RCEH i Bangladesh behandlet vi i starten av utsendingen for det meste pasienter med gamle sår, abscesser, voldsskader, hudinfeksjoner, dehydrering, underernæring eller diaré.

Etter hvert ble det færre personer med gamle skader, men fortsatt ble mange skadet, blant annet $\mathrm{i}$ trafikkulykker. Det var utbrudd av difteri og meslinger i flyktningleiren. Ellers forekom dehydrering, underernæring, sår og infeksjoner.

Føde- og barselhjelp var noe av det mest sentrale tilbudet ved feltsykehuset. I den første tiden var dødfødsler vanlig, gjerne flere ganger i uken, men antallet dødfødsler gikk ned etter hvert som helsetilbudet til flyktningene ble bedre kjent blant flyktningene.

\section{三 «Føde- og barselhjelp var noe av det mest sentrale tilbudet ved feltsykehuset.»}

Nedenfor beskrives to eksempler på situasjoner som var helt vanlige ved feltsykehuset og viser kompleksiteten og utfordringene ved beslutningsprosessen.

For det første var det stadige dødfødsler ved sykehuset fordi mange fødende kom for seint til at vi kunne redde barnet, noe som utgjorde en stor utfordring for alle involverte. 
Et annet eksempel på utfordringer var at etter en dødfødsel ville ikke mor eller familien vite av det døde fosteret. Et forslag om å brenne det døde fosteret i en forbrenningsovn (laget for destruksjon av sprøytespisser, nåler, kniver og biologisk avfall) ble forkastet; å brenne døde strider for øvrig mot muslimsk skikk. Løsningen ble at en imam som arbeidet i det psykososiale teamet (PSS), tok med seg fosteret og begravde det på gravplassen.

\section{Senger i hagen}

Det var en stor kvinneavdeling, en stor barneavdeling og en noe mindre mannsavdeling i Rubber Garden. På grunn av varmen ble ofte sengene båret ut i hagen, der pasienten kunne ligge under skyggefulle gummitrær.

Et eksempel på et vanlig syn i leiren var at en ung mann lå ute i hagen med foten i strekk etter et lårbeinsbrudd som følge av en trafikkulykke. Strekkbehandling av brudd er noe en vanligvis kun utfører på barn i Norge.

Mange hjelpearbeidere har hørt historier der pasienter med ekstern fiksasjon ble skrevet ut, og det kirurgiske teamet reiste igjen, og ingen kunne hjelpe pasientene med å fjerne fiksasjonen.

Bruk av strekkbehandling på voksne pasienter, og ikke ekstern fiksasjon, ble derfor gjort for å øke pasientsikkerheten. En må ofte ta helt andre hensyn i katastrofeområder enn under mer kontrollerte forhold.

\section{Hjelp av pårørende}


WHOs fastsatte minimumsstandard for

bemanningsnorm i EMT 2, med en sykepleierratio per

pasient satt 1:8 (5), kan virke som en for lav

bemanning. Imidlertid er det slik at i mange land der

feltsykehusene har vært sendt ut, for eksempel etter

jordskjelvet i Chautara i Nepal i 2015, er det helt

vanlig at den pårørende tar seg av pasientens hygiene.

Den pårørende sover også ofte under pasientens seng

om natten.

At pårørende ligger under sengen til pasienten, kan høres underlig og svært fremmed ut, men i forbindelse med mange katastrofer har de pårørende mistet nesten alt de eier. De pårørende får dermed også hjelp ved at de ligger på isopormatten under teltbunnen som mange av sykehusteltene er utstyrt med. De pårørende får i tillegg mat.

Det er ikke uvanlig at pasientene er svært redde for sykehus og helsepersonell fordi de er i et totalt fremmed miljø. Når pårørende er til stede på sykehuset, sikrer det at det alltid er noen hos pasienten, og de pårørende kan også bli litt tryggere i situasjonen.

For ytterligere å illustrere hvilke harde realiteter pasienter og pårørende er $\mathrm{i}$, har hjelpepersonell flere ganger opplevd at ferdigbehandlede pasienter ikke vil forlate sykehuset, fordi de der har tak over hodet, en seng og de får mat tre ganger om dagen. Likevel må de skrives ut og dra, fordi nye pasienter venter.

\section{Sykloner og monsun}

Bangladesh blir omtrent årlig utsatt for kraftige sykloner, og monsunsesongen starter i juni med svært store nedbørsmengder. Det var gravd dype kanaler mellom teltene. Vi regnet med at trærne på bananplantasjen i Cox's Bazar ville gi i alle fall litt beskyttelse mot syklonen, når og hvis den kom. 
Flyktningene bor i et kupert landskap av leire og jord, og det er nesten ingen sikre boliger. De bor i skur av plast, bambus og presenning.
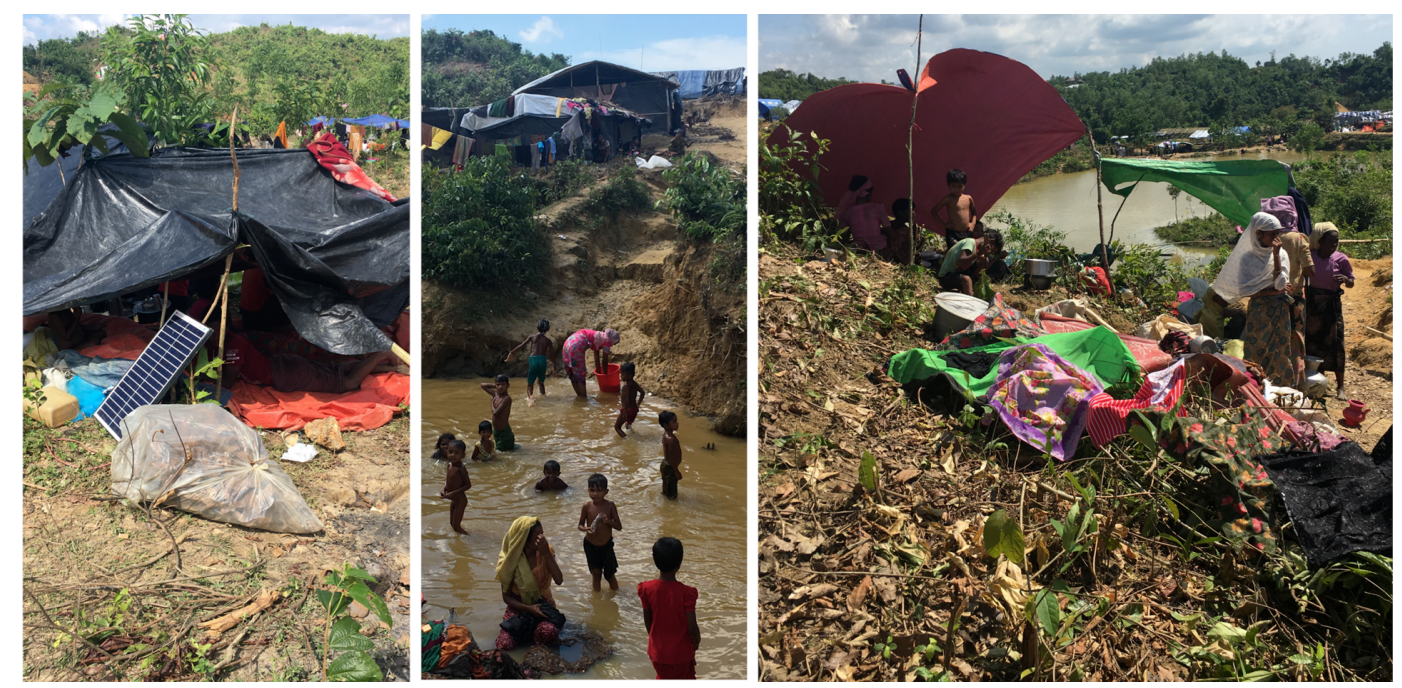

ENKLE KÅR: Flyktningene gjør så godt de kan for å skape et nytt hjem. Det er mangel på rent vann i flyktningleiren. Foto: Anne Kristine Jensen (Foto: Anne Kristine Jensen)

Mange organisasjoner, FN, hæren og myndighetene i Bangladesh forbereder seg på syklonsesongen så godt som mulig, og det gjør flyktningene også. Det er beredskapsansvarlige og et eget varslingssystem i hver underleir. Det mulige skadeomfanget er enormt.

I 2018 kom det ingen syklon til dette område. Uansett er beredskap og forberedelser viktig. Det er etablert et varslingssystem med fra 72 til 96 timers varsel der det er mulig å forutse hvor syklonen treffer, og hvor kraftig syklonen er. Et analogt system med varsling med flagg er etablert inne i den gigantiske flyktningleiren.

Monsunsesongen kommer i juni med massive nedbørsmengder. Flyktningleirene som ligger i et kupert landskap, dekket av sand og leire, er svært utsatte for jordskred og flom. Det har blitt avholdt masseskadeøvelser og beredskapsøvelser for frivillige og flyktninger. 
Det ble leid inn containere til sykehuset, slik at inventar og flere av teltene kunne få plass der i tilfelle et direkte treff av en syklon. Utfordringen er at personalet som er ved sykehuset nå, ikke er vant til å sette opp telt eller innrede det, noe som er en stor utfordring. Fordelen er at folk i Bangladesh er vant til sykloner, hæren har beredskapslager, og BDCS er forberedt så langt det går. Men ingen myndighet eller organisasjon kan løse en slik mulig krise alene under monsunen eller hvis syklonen kommer.

\section{Kunnskapsoverføring i praksis}

Ber hver dag en kurv grus til en haug og du kan bygge et fjell (16).

Det internasjonale engasjementet ved feltsykehuset $\mathrm{i}$ Rubber Garden, der Norges Røde Kors hadde ansvaret for utsending og drift i samarbeid med IFRC og BDRC, og der Finland Røde Kors tok over hovedansvaret fra mars 2018, tok slutt ved årsskifte 2018-2019.

Feltsykehuset i Rubber Garden drives fra 1. januar 2019 helt selvstendig av BDRCS. Fra å være usikre og uvante med arbeidsforholdene er det lokale helsepersonellet blitt mer sikre og trygge i arbeidet, selv om de fleste av dem var relativt nyutdannede sykepleiere og leger da de begynte. Dette skyldes at personellet har vært stabile det siste halve året og arbeidet på samme sted og sammen med mer erfarent personell over tid. Det lokale helsepersonellet fornyet sine kontrakter i mars 2019. De har hatt mange utfordringer med nytt utstyr og fremmed arbeidsmiljø, men de har mestret uvante forhold og har tatt på seg et stort ansvar. 
Ved feltsykehuset har det ikke lyktes å rekruttere spesialister som gynekologer og anestesileger ved utgangen av april 2019, men det arbeides med dette for øye. Bortsett fra det er det høy aktivitet på poliklinikken med i gjennomsnitt over 100 pasienter hver dag, og der det er 10-15 inneliggende pasienter. Selv om det er færre akutte innleggelser, er det fortsatt en del ulykker. Protokoller og prosedyrer for eksempel ved triagering er velkjent, og det foreligger et utstrakt samarbeid med de andre feltsykehusene i forhold til overføring av pasient til kirurgisk behandling. Tallet på dødfødsler har også gått ned, og det er rimelig god kontroll på infeksjonssykdommer.

\section{三 «Tallet på dødfødsler har også gått ned, og det er rimelig god kontroll på infeksjonssykdommer.»}

BDRCS har planer om å drive feltsykehuset også etter 2019. Slik det ser ut nå, er det lite som tyder på at flyktningene vil returnere til Myanmar med det første. Dette kan på lang sikt også føre til at mange organisasjoner tekker seg ut eller skalerer ned sine programmer. Det ser en allerede tegn til.

Det var derfor en stor positiv nyhet da det ble klart at Qatar Røde Halvmåne går inn med betydelig finansiering av feltsykehuset, noe som også medfører at de fleste av teltene blir erstattet med prefabrikkerte hus.

Kompetanseoverføring mellom lokalt personell og internasjonale delegater er sentralt i feltsykehus. Dette er en læringsprosess som går to veier. Lokalt helsepersonell lærer om arbeid under feltforhold, og BDRCS kommer til å fortsette arbeidet ved feltsykehuset, og har et langsiktig perspektiv på dette arbeidet. 
Oppretting av psykososiale team (PSS) har vært gjort på bakgrunn av slik lærdom, sammen med støtte av empirisk kunnskap, som har ført til at PSS nå er en integrert del ved mange deployeringer.

Vanskene med å rekruttere legespesialister kunne ikke løses med å fortsette med korte rotasjoner av internasjonalt personell. Som regel blir ikke feltsykehusene sendt hjem igjen, men overført til lokalt Røde Kors eller Halvmåne eller til myndighetene for å styrke beredskapen. Slik det for eksempel ble gjort med et stort kirurgisk feltsykehus etter tsunamien i 2005, som ble gitt til indonesiske helsemyndigheter og indonesisk Røde Kors, og gjenbrukt flere ganger. Her gjøres det annerledes: Sykehuset er overtatt av BDRCS, men det er fortsatt i drift, og det er planer om oppgradering. Flyktningene vil være her lenge, og BDRCS er seg sitt ansvar bevisst.

\section{Referanser}

1. The International Federation of Red Cross and Red Crescent Societies. Emergency plan of action operation update. Emergency appeal revision 5. IFRC; 01.05.2019. Revised Appeal n MDRBD018.

Tilgjengelig fra: https://www.ifrc.org/en/publicationsand-reports/appeals/ (nedlastet 21.04.2019).

2. Elster K. Amnesty: Setter Rakhine i flammer for å drive ut Rohingyane. Oslo: NRK Urix; 14.09.2017. Tilgjengelig fra: https://www.nrk.no/urix/amnesty_setter-rakhine-i-flammer-for-a-drive-ut-rohingyaene1.13688738 (nedlastet 21.04.2019).

3. Siterte sitater. Friedrich Nietzsche [internett]. Siterte sitater [sitert 28.05.2019]. Tilgjengelig fra: https://www.ordtak.no/index.php?fnFriedrich \& enNietzsche \& side $=3$ 
4. Røde Kors. Nødhjelp og katastrofer [internett].

Oslo: Røde Kors [sitert 21.04.2019]. Tilgjengelig

fra: https://www.rodekors.no/vart-arbeid/nodhjelp-og-

katastrofer/

5. Norton I, Von Schreeb J, Aitken P, Herard P, Lajolo C. Classification and minimum standards for foreign medical teams in sudden onset disasters.

Geneva: WHO Press; 2013.

6. Norge styrker beredskapen. Tilgjengelig fra: https://www.dsb.no/nyhetsarkiv/2018/norge-styrkerberedskapen/ (nedlastet 22.04.2019).

7. The International Federation of Red Cross and Red Crescent Societies. Emergency response units (ERUs) [internett]. IFRC [sitert 21.04.2019].

Tilgjengelig fra: https://www.ifrc.org/en/what-wedo/disaster-management/responding/disaster-responsesystem/dr-tools-and-systems/eru/

8. NTB. Våger ikke vende tilbake [internett]. Oslo: NRK Urix; 22.01.2018 [sitert 22.04.2019].

Tilgjengelig fra: https://www.nrk.no/urix/utsetterhjemsendelsen-av-rohingya-flyktninger-1.13878702

9. Kipling R. The Ballad of East and West [internett]. Bartleby.com [sitert 28.05.2019]. Tilgjengelig fra: https://www.bartleby.com/246/1129.html

10. Cohen IB. Florence Nightingale. Scientific American. 1984 mars;250(3):128-37.

11. Harwey-Karlsson J, Jeffery S, Kerr A, Schmidt H. Hospitals for war-wounded. A practical guide for setting up and running a surgical hospital in an area of armed conflict. Genève: International Committee of the Red Cross; 1998.

12. Giannou C, Baldan M. War surgery. Working with limited recourses in armed conflicts and other situations of violence. ICRC. Mai 2010;1. 
13. Giannou C, Baldan M, Molde Å. War surgery.

Working with limited recourses in armed conflicts and other situations of violence. ICRC. April 2013;2.

14. Helveg S. ICRC nursing guidelines. Genève: ICRC; 2019.

15. Reynolds T, Roddie N, Tenner A, Geduld H.

Basic emergency care. Approach to the ill and injured. World Health Organization (WHO) and the International Committee of the Red Cross (ICRC); 2018. Tilgjengelig fra https://www.who.int/emergencycare/publications/Basi c-Emergency-Care/en/

16. Siterte sitater. Confucius [internett]. Siterte sitater [sitert 28.05.2019]. Tilgjengelig fra: https://www.ordtak.no/index.php?fn= \& enkonfucius \& side $=2$ 